\title{
Effect of leaf powder of giloy (Tinospora cordifolia) in fish feed on survival and growth of post larvae of Catla catla
}

\author{
Parul Upreti and R.S. Chauhan* \\ - 263145 (Uttarakhand), INDIA \\ *Corresponding author. E-mail: rikhi812chauhan@gmail.com \\ Received: June 19, 2017; Revised received: September 1, 2017; Accepted: January 20, 2018
}

Department of Aquaculture, College of Fisheries, G. B. Pant University of Agriculture and Technology, Pantnagar

\begin{abstract}
The study was designed to evaluate the effect of leaf powder of Giloy (Tinospora cordifolia) in fish feed on survival and growth of post larvae of Catla catla. The experiment consisted of five treatments (T1, T2, T3, T4 and T5) in triplicate. The artificial feed was prepared from de-oiled groundnut cake (49.5\%), de-oiled rice bran (49.5\%) and vitamin - mineral mixture $(1 \%)$. The leaf powder of giloy was incorporated into larval feed at various rates. In treatment T1 (control), no leaf powder was incorporated in the feed. In T2, T3, T4 and T5 leaf powder was mixed at the rate of $0.25 \%, 0.5 \%, 0.75 \%$ and $1 \%$, respectively. One hundred post larvae of $C$. catla of uniform size $(7.3 \mathrm{~mm}$ length, $1.5 \mathrm{mg}$ weight) were stocked in each of $5 \times 3=15$ tanks. The larvae were fed twice in a day. The water quality parameters were regularly monitored. The survival rate of post larvae in T1, T2, T3, T4 and T5 were recorded as 95.3, 94.3, 97.0, 98.6 and 100\%, respectively. Post larvae fed with diet incorporated with $1 \%$ leaf powder achieved significantly enhanced $(P<0.05)$ specific growth rate $(6.97 \%)$, feed conversion ratio $(2.41)$ and gross conversion efficiency (0.415). The study revealed that giloy leaf powder has very good growth promoting potential in raising post larvae of carp. Thus, it is recommended that the leaf powder of giloy may be incorporated in fish feed upto $1 \%$ for enhancing growth and survival of post larvae of carp fishes up to fry stage.
\end{abstract}

Keywords: Feed conversion ratio, Gross conversion efficiency, Specific growth rate, Tinospora cordifolia

\section{INTRODUCTION}

Aquaculture is one of the fastest growing food producing sectors in the world. It provides -- $44.14 \%$ of the world's fish production for human consumption. Asia contributes $88.91 \%$ of the total global aquaculture production (FAO, 2016). Major Indian and Chinese carps are main cultivated species contributing more than $70 \%$ in world aquaculture production. India is the second largest fish producer in the world. Around 14.49 million people are involved in fisheries sector for livelihood security(DAHDF, 2016). The prime requirement for enhancing aquaculture production is availability of quality seed. Though huge amount of carp seed is being produced in India, the fish hatcheries producing seed do not follow any genetics standards. The selection of brood stock is done in such a way that it has become counterproductive because of the desire to choose late maturing and slow growing brooders (Eknath and Doyle, 1985). By improving the feeding and nutrition of brood stock, improvement in quality of egg and sperm is recorded (Izquierdo et al., 2001).

The larval stages are most critical stages in life cycle of fish as the larvae are defenceless against predators, diseases outbreak, environmental conditions and stress. The average survival rate is very poor mainly due to non-adoption of appropriate larval care protocols. The environmental factors (Jezierska et al., 1979)and feeding mode, mouth size and food particles size(Hartman, 1983)affect the survival of fish larvae. The fish production is increasing significantly over the past few decades mainly due to adoption of the intensive fish culture practices. These practices are the major factors that make the fish susceptible to disease. During the last few years probiotics and herbs have gained attention for their use in fish culture operations for promoting growth and disease resistance. They offer many advantages to overcome the limitations and side effects of antibiotics and other drugs and result into high production through enhanced growth and disease prevention (Das -, 2008; Sahu et al., 2008).

Plants are natural sources of cheaper and safer chemicals (Citarasu, 2010). Plant products have various attributes like anti-stress, anti-tumour, anti-pyretic, tonic, antimicrobial, growth promotion, appetite stimulation and immunostimulation in aquaculture practices. In India, many herbal preparations are used for the enhancement of growth in human beings. Some of these herbs have also proved effective as a growth promoter in aquaculture (Olusola et al., 2013).

A number of plant biomaterials have been tried for growth promotion and immunity enhancement in fish 
like Meliaazedarach in formulated diet of C. catla (Rajeshwari et al., 2015), Zingiberofficinale powder in feed of the Indian major carp (C. catla) infected by Aeromonas hydrophila (Arulvasu et al., 2013), Coriandrum sativum in C. catla (Innocent et al., 2011), Glycyrizzha glabra in Cirrhinus mrigala (Kumar et al., 2007), Z. officinale and Curcuma longa in C. mrigala (Sivagurunathan et al., 2011)and T.-cordifolia leaf powder in fingerlings of Amur carp (Anita et al., 2016).

$T$. cordifolia is a large deciduous, climbing shrub distributed throughout the tropical Indian subcontinent. It is commonly known as Guduchi, Giloy, Amrita and Gurcha. "Amrita" which is a hindi term refering to elixir that delay aging in humans and keep them young. All parts of this plant like fruits, leaves, stem and seeds are useful. A variety of chemicals have been isolated from $T$. cordifolia belonging to different classes such as alkaloids, lactones, steroids, diterpenoids and glycosides (Sinha et al., 2004).

Indian aquaculture has been growing at a fast pace with freshwater culture contributing over $95 \%$ of the production. The Indian major carp, $C$. catla, is a promising species for aquaculture exploitation with its rapid growth and good market potential. It is economically important South Asian freshwater fish. On the basis of above mentioned points, the present study was made with the prime objective of evaluation of growth and survival of post larvae of Indian major carp C.catla fed with $T$-cordifolia leaf powder incorporated diet.

\section{MATERIALS AND METHODS}

Experiment Design: The experiment consisted of 5 treatments (T1, T2, T3, T4 and T5) in triplicate. In total, 15 plastic tubs were properly arranged and aerators were setup therein. Each tub was stocked with 100 post larvae of $C$. catla. The experiment lasted for 21 days which is normal period for growth of post larvae upto fry stage in carps.

Collection and maintenance of post larvae: Healthy post larvae of $C$. catla, weighing $1.5 \pm 0.01 \mathrm{mg}$ were collected from Fish Seed Hatchery, College of Fisheries, G.B. Pant University of Agriculture and Technology, Pantnagar and kept in oxygenated water in the plastic tubs of 60 litre water capacity. Fifty percent water was exchanged daily. The tubs were cleaned every alternate day.

Feed preparation and feeding of post larvae: The feed for the post larvae of $C$. catla was prepared using finely powdered de-oiled groundnut cake $(49.5 \%)$, deoiled rice bran $(49.5 \%)$ and vitamin-mineral mixture (1.0\%). The experimental diets were prepared by adding T. cordifolia leaf powder at the rate of $0.25 \%$ in D2 diet, $0.5 \%$ in D3 diet, $0.75 \%$ in D4 diet and $1 \%$ in D5 diet while control diet D1 was with no supplementation of leaf powder. The proximate analysis of the formulated feed is presented in Table 1.In control treat- ment $\mathrm{T} 1$, the fishes were fed with normal diet whereas in other treatments the larvae were fed with diet having supplementation of leaf powder of T. cordifolia@ $0.25 \%$ in $\mathrm{T} 2,0.5 \%$ in $\mathrm{T} 3,0.75 \%$ in $\mathrm{T} 4$ and $1 \%$ in $\mathrm{T} 5$. The rate of feeding of post larvae has been detailed in Table 2. The feed was given in two equal instalments daily, during morning and afternoon. In addition, post larvae were also fed with natural food i.e. plankton ( 2 $\mathrm{ml}$ ) in each tub every alternate day.

Water quality analysis: Various water quality parameters viz. water temperature $\left({ }^{0} \mathrm{C}\right), \mathrm{pH}$, dissolved oxygen $(\mathrm{mg} / \mathrm{l})$, free carbon dioxide $(\mathrm{mg} / \mathrm{l})$ and total alkalinity $(\mathrm{mg} / \mathrm{l})$ were monitored regularly. Water temperature was measured using mercury thermometer while $\mathrm{pH}$ was recorded by digital $\mathrm{pH}$ meter. Dissolved oxygen, free carbon dioxide and total alkalinity were estimated as per methods of American Public Health Association (2012).

Survival and growth parameters: The rate of survival of post larvae in each experimental tub was determined by comparing the total larvae stocked initially to the larvae recovered at the end of the experiment. The net weight gain (NWG), specific growth rate (SGR), feed conversion ratio (FCR) and gross conversion efficiency (GCE)were calculated as given below:

NWG = Average final body weight $(\mathrm{g})$ - Average initial body weight $(\mathrm{g})$

SGR \% $=[\log \{$ final weight $\}-\log \{$ initial weight $\} / \mathrm{t}$ (time interval in days) $\times 100$

$\mathbf{F C R}=$ Dry weight of food given in $\mathrm{g} /$ Wet weight gain in $\mathrm{g}$

GCE $=$ Wet weight gain in $\mathrm{g} /$ dry weight of feed given in $\mathrm{g}$

Statistical analysis: The observations of the present study were analyzed using statistical package (SPSS, version 16.0 for windows, SPSS Inc., Chicago, USA). The differences among the different treatment were determined for significance using ANOVA (Analysis of variance). The level of significance was set at $\mathrm{p}<0.05$ and results recorded as mean \pm S.E.

\section{RESULTS AND DISCUSSION}

Water quality parameters: The physico-chemical parameters like water temperature, $\mathrm{pH}$, dissolved oxygen, free carbon dioxide and total alkalinity play a vital role in the survival and growth of the aquatic organisms. These affect the physiology and other metabolic activities of the fishes. The summarised observations on various water quality parameters have been recorded in Table 3. The ranges of temperature (26.0-

Table 1.Proximate composition of experimental feed.

\begin{tabular}{lll}
\hline Sl. No. & Contents & $\mathbf{\%}$ \\
\hline 1 & Moisture & 11.9 \\
2 & Crude protein & 25.8 \\
3 & Crude fat & 7.8 \\
4 & Crude fibre & 6.3 \\
5 & Ash & 7.0 \\
\hline
\end{tabular}


Table 2.Feeding rate of post larvae of Catla catla by experimental feed.

\begin{tabular}{|c|c|c|c|c|c|}
\hline \multicolumn{4}{|l|}{ Feeding rate } & \multicolumn{2}{|c|}{ Feeding days } \\
\hline \multicolumn{4}{|c|}{ Equal to the total initial weight of post larvae } & \multicolumn{2}{|l|}{ First 2 days } \\
\hline \multicolumn{4}{|c|}{1.5 times of total initial weight of post larvae } & \multicolumn{2}{|l|}{ 3-4 days } \\
\hline \multicolumn{4}{|c|}{2 times of total initial weight of post larvae } & \multicolumn{2}{|l|}{ 5-6 days } \\
\hline \multicolumn{4}{|c|}{2.5 times of total initial weight of post larvae } & \multicolumn{2}{|l|}{ 7-8 days } \\
\hline \multicolumn{4}{|c|}{3 times of total initial weight of post larvae } & \multicolumn{2}{|l|}{$9-10$ days } \\
\hline \multicolumn{4}{|c|}{3.5 times of total initial weight of post larvae } & \multicolumn{2}{|l|}{ 11-12 days } \\
\hline \multicolumn{4}{|c|}{4 times of total initial weight of post larvae } & \multicolumn{2}{|l|}{$13-14$ days } \\
\hline \multicolumn{4}{|c|}{4.5 times of total initial weight of post larvae } & \multicolumn{2}{|l|}{$15-17$ days } \\
\hline \multicolumn{4}{|c|}{5 times of total initial weight of post larvae } & \multicolumn{2}{|l|}{$18-21$ days } \\
\hline ble 3.Profile of water & rameters ( & in diffor & & & \\
\hline \multirow[t]{2}{*}{ Parameters } & \multicolumn{5}{|c|}{ Treatments } \\
\hline & $\begin{array}{c}\text { T1/D1Range } \\
(\text { mean } \pm \text { SE })\end{array}$ & $\begin{array}{c}\text { T2/D2 Range } \\
(\text { mean } \pm \text { SE })\end{array}$ & $\begin{array}{c}\text { T3/D3 Range } \\
(\text { mean } \pm \text { SE })\end{array}$ & $\begin{array}{c}\text { T4/D4 Range } \\
(\text { mean } \pm \text { SE) }\end{array}$ & $\begin{array}{c}\text { T5/D5 Range } \\
(\text { mean } \pm \text { SE) }\end{array}$ \\
\hline Temperature $\left({ }^{\circ} \mathrm{C}\right)$ & $\begin{array}{c}26.0-29.0 \\
(27.97 \pm 0.01)\end{array}$ & $\begin{array}{c}26.0-29.5 \\
(27.99 \pm 0.03)\end{array}$ & $\begin{array}{c}26.5-29.5 \\
(27.98 \pm 0.04)\end{array}$ & $\begin{array}{c}26.5-29.0 \\
(28.01 \pm 0.03)\end{array}$ & $\begin{array}{c}26.0-29.0 \\
(27.98 \pm 0.03)\end{array}$ \\
\hline $\mathrm{pH}$ & $\begin{array}{c}7.0-8.0 \\
(7.48 \pm 0.02)\end{array}$ & $\begin{array}{c}7.0-8.2 \\
(7.40 \pm 0.02)\end{array}$ & $\begin{array}{c}6.8-7.8 \\
(7.32 \pm 0.02)\end{array}$ & $\begin{array}{c}6.8-8.0 \\
(7.35 \pm 0.03)\end{array}$ & $\begin{array}{c}7.0-8.0 \\
(7.49 \pm 0.01)\end{array}$ \\
\hline Dissolved oxygen $(\mathrm{mg} / \mathrm{l})$ & $\begin{array}{c}6.0-8.0 \\
(7.03 \pm 0.01)\end{array}$ & $\begin{array}{c}6.2-7.8 \\
(7.04 \pm 0.02)\end{array}$ & $\begin{array}{c}6.2-8.0 \\
(7.17 \pm 0.01)\end{array}$ & $\begin{array}{c}6.4-8.0 \\
(7.22 \pm 0.03)\end{array}$ & $\begin{array}{c}6.1-8.0 \\
(7.10 \pm 0.05)\end{array}$ \\
\hline & Nil & Nil & Nil & Nil & Nil \\
\hline Total alkalinity $(\mathrm{mg} / \mathrm{l})$ & $\begin{array}{c}98-265 \\
(168.0 \pm 0.4)\end{array}$ & $\begin{array}{c}108-260 \\
(167.8 \pm 0.2)\end{array}$ & $\begin{array}{c}110-264 \\
(164.03 \pm 0.6)\end{array}$ & $\begin{array}{c}115-255 \\
(161.95 \pm 0.9)\end{array}$ & $\begin{array}{c}110-265 \\
(165.2 \pm 1.5)\end{array}$ \\
\hline
\end{tabular}

T1/D1- Treatment 1 where post larvae were fed with feed without leaf powder of $T$. cordifolia, T2/D2- Treatment 2 where post larvae were fed with feed containing $0.25 \%$ leaf powder of $T$. cordifolia, T3/D3- Treatment 3 where post larvae were fed with feed containing $0.50 \%$ leaf powder of T. cordifolia, T4/D4- Treatment 4 where post larvae were fed with feed containing $0.75 \%$ leaf powder of $T$. cordifolia, T5/D5- Treatment 5 where post larvae were fed with feed containing $1.0 \%$ leaf powder of $T$. cordifolia.

Table 4.Survival, growth and feed conversion in Catla catla post larvae fed with Tinospora cordifolia added diets

\begin{tabular}{lccccc}
\hline \multicolumn{5}{c}{ Treatments } \\
\hline Parameters & T1/D1 (control) & T2/D2 (0.25\%) & T3/D3 (0.5\%) & T4/D4 (0.75\%) & T5/D5 (1\%) \\
\hline Initial body weight (g) & $0.0015 \pm 0.01$ & $0.0015 \pm 0.01$ & $0.0015 \pm 0.01$ & $0.0015 \pm 0.01$ & $0.0015 \pm 0.01$ \\
Final body weight (g) & $0.0122 \pm 0.001$ & $0.0139 \pm 0.001$ & $0.0210 \pm 0.01$ & $0.039 \pm 0.001$ & $0.044 \pm 0.001$ \\
NWG (g) & $0.011 \pm 0.001$ & $0.012 \pm 0.001$ & $0.02 \pm 0.01$ & $0.037 \pm 0.001$ & $0.043 \pm 0.002$ \\
SGR (\%) & $4.30 \pm 0.20$ & $4.82 \pm 0.11$ & $5.29 \pm 0.44$ & $5.79 \pm 0.30$ & $6.97 \pm 0.10$ \\
FCR & $6.51 \pm 0.20$ & $6.87 \pm 0.41$ & $5.35 \pm 0.11$ & $2.74 \pm 0.17$ & $2.41 \pm 0.18$ \\
GCE & $0.17 \pm 0.02$ & $0.15 \pm 0.01$ & $0.18 \pm 0.02$ & $0.36 \pm 0.01$ & $0.415 \pm 0.02$ \\
Survival (\%) & $95.3 \pm 0.8$ & $94.3 \pm 3.1$ & $97.0 \pm 1.1$ & $98.6 \pm 0.2$ & $100.0 \pm 0.0$ \\
\hline
\end{tabular}

T1/D1- Treatment 1 where post larvae were fed with feed without leaf powder of $T$. cordifolia, T2/D2- Treatment 2 where post larvae were fed with feed containing $0.25 \%$ leaf powder of $T$. cordifolia, T3/D3- Treatment 3 where post larvae were fed with feed containing $0.50 \%$ leaf powder of $T$. cordifolia, T4/D4- Treatment 4 where post larvae were fed with feed containing $0.75 \%$ leaf powder of $T$. cordifolia, T5/D5- Treatment 5 where post larvae were fed with feed containing $1.0 \%$ leaf powder of $T$. cordifolia.

$\left.29.5^{\circ} \mathrm{C}\right), \mathrm{pH}(6.8-8.2)$, dissolved oxygen $(6.0-8.0 \mathrm{mg} / \mathrm{l})$, free carbon dioxide (Nil) and total alkalinity (98-265 $\mathrm{mg} / \mathrm{l}$ ) in the present study were within the favourable limits for carp rearing as also reported by Jhingaran (1991) for Indian major carps (water temperature 18.3 $-37.8^{\circ} \mathrm{C}$ and $\left.\mathrm{pH} 6.5-9.0\right)$, Chauhan (2001) for carps (pH 7.5 -9.0 and dissolved oxygen $6.5-10.5 \mathrm{mg} / \mathrm{l}$ ), Chauhan (2014) for rearing of Cyprinus carpio (water temperature $16.0-21.2^{\circ} \mathrm{C}$ and dissolved oxygen little above $5 \mathrm{mg} / \mathrm{l}$ ), Nazir et al. (2015) for Labeo rohita fingerlings (water temperature $19.7-20.6^{\circ} \mathrm{C}$, dissolved oxygen $6.8-7.5 \mathrm{mg} / 1$, free $\mathrm{CO}_{2} 0.28-0.55 \mathrm{mg} /$ 1 and total alkalinity $103.8-113.9 \mathrm{mg} / \mathrm{l})$ and Arya et al. (2016) for Labeo rohita (water temperature 19.9 - $20.9^{\circ} \mathrm{C}$, dissolved oxygen $7.44-7.63 \mathrm{mg} / \mathrm{l}$, free $\mathrm{CO}_{2}$ $0.29-0.4 \mathrm{mg} / \mathrm{l}$ and total alkalinity $106.6-110.7 \mathrm{mg} / \mathrm{l}$ ). The analysis of variance revealed that the differences in water temperature, $\mathrm{pH}$, dissolved oxygen, free carbon dioxide and total alkalinity amongst different treatments were statistically non-significant $(\mathrm{P}<0.05)$.

Survival: The observations on survival, growth and feed conversion of post larvae of $C$. catla in different treatments have been included in Table 4.At the end of the experiment, $100 \%$ survival was observed in T5 treatment with $1 \%$ supplementation of $T$. cordifolia whereas minimum average survival of $94.3 \pm 3.1 \%$ was seen in T2 treatment with $0.25 \%$ supplementation of giloy leaf powder. This shows that the herb T. cordi- 
folia is helpful in enhancing the survival of the fish. The difference between the survival percentage of different treatments were statistically non - significant. The results are in conformity with the findings of Arulvasu et al. (2013) who got relative percentage survival of $100 \%$ in $C$. catla fed with $Z$. officinale $(1000 \mathrm{mg} / \mathrm{kg})$ incorporated diet.

Specific growth rate: The highest net weight gain $(0.043 \mathrm{~g})$ and specific growth rate $(6.97 \%)$ were recorded in treatment T5 followed by T4, T3, T2 and T1. The values of NWG and SGR recorded in T5 were significantly $(p<0.05)$ higher in comparison to $\mathrm{T} 1$ (control) and other treatments. The results are in accordance with Kumar et al. (2007) who observed that fingerlings of $C$. mrigala when fed with $0.3 \%$ mulethi achieved highest weight gain of $24 \%$ as compared to other treatments in 60 days culture period. Anita et al. (2016) also recorded significantly higher SGR in Cyprinus carpio haematopterus fed with $T$. cordifolia incorporated feed $(0.25 \%, 0.5 \%$ and $1 \%)$.

Feed conversion ratio: The minimum FCR was seen in T5 (Table 4) (with $1 \%$ leaf powder supplementation) which was significantly different from T1, T2, $\mathrm{T} 3$ and T4 $(\mathrm{p}<0.05)$. The mean of treatments display that best FCR was recorded in T5 (2.41) followed by T4 (2.74), T3 (5.35), T2 (6.87) and control T1 (6.51). Kour et al. (2004) conducted a feeding trial on $C$. mrigala to assess the impact of Bala (Sida cordifolia) herb mixed with ground nut oil cake and rice bran (1:1). They concluded that the value of FCR was better in fishes fed with herb supplemented feed in comparison with other treatment in 60 days trial.

Gross conversion efficiency: The highest GCE was observed in T5 treatment (Table 4) (with $1 \%$ leaf powder supplementation) which was significantly ( $\mathrm{P}<$ $0.05)$ different from all other treatments. Kumari et al. (2007) observed the enhanced survival and growth of larvae of rohu fed with diet containing polyherbal mixture (ImmuPlus) of Withania somnifera (Ashwagandha), T. cordifolia (Giloy), Ocimum sanctum (Tulsi) and Emblica officinalis(Amlaki) at the rate of $0.5 \mathrm{~g}$ ImmuPlus $/ \mathrm{kg}$ feed. Punitha et al. (2008) also got significantly $(\mathrm{P}<0.05)$ increased survival and growth rate in grouper Epinephelus tauvina juveniles raised on diet containing extracts $(400 \mathrm{mg} / \mathrm{kg}$ diet $)$ of herbs like Cynodon dactylon, Tridax procumbens, Phyllanthus niruri, Piper longum and Zingiber officinale mixed in equal proportions of the all- plant extracts. The results of the present study support the findings of Anita et al. (2016) who got enhanced growth in amur carp (Cyprinus carpio haematopterus) fingerlings fed with $T$. cordifolia incorporated $(0.75 \%)$ diet.

The possible reason of enhanced survival and growth of $C$. catla post larvae may be growth promoting and immunostimulatory potential of $T$. cordifolia leaf powder as also reported by Anita et al. (2016) who record- ed significantly $(\mathrm{P}<0.05)$ increased values of $\mathrm{SGR}$ $(1 \%)$, total leukocyte count $\left(53.84 \times 10^{3} / \mu \mathrm{l}\right)$ and total serum protein $(12.35 \mathrm{~g} / \mathrm{dL})$ in C. carpio haematopterus fingerlings fed with $T$. cordifolia $(0.75 \%)$ incorporated diet.

\section{Conclusion}

On the basis of the present investigation, it could be summarized that inclusion of leaf powder of medicinal herb Giloy ( $T$. cordifolia) in carp feed at the rate of 1.0 $\%$ has potential for enhancing the survival and growth performance of the post larvae of carp fish $C$. catla. It can be inferred from the study that leaf powder of Giloy (T. cordifolia) can be safely incorporated up to $1 \%$ level in feed of post larvae of carp. Development of better feed technologies need to be developed for utilisation of herbal / medicinal plants extracts so that farmers can easily purchase such cheap herbal growth promoters and immunostimulators and use them for enhanced sustainable fish production.

\section{REFERENCES}

Anita, Dubey, M. K., Khati, A. and Chauhan, R.S. (2016).Immunostimulatory and growth promoting potential of Tinospora cordifolia (Thunb.)Miers on fingerlings of Amur carp. Indian Journal of Experimental Biology, 54:659-663.

American Public Health Association (2012). Standard Methods for the Examination of Water and Wastewater, 22th ed. American Public Health Association, Washington D.C., 1496p.

Arulvasu, C., Mani, K., Chandhirasekar, D., Prabhu, D. and Sivagnanam, S. (2013). Effect of dietary administration of Zingiber officinaleon growth, survival and immune response of Indian major carp, Catla catla (Ham.). International Journal of Pharmacy and Pharmaceutical Sciences, 5(2):108-115.

Arya, P., Nazir, I. and Chauhan, R.S. (2016).Evaluation of growth performance in fingerlings of Indian major carp Labeo rohita fed with nutraceuticalStimulin incorporated diets. J. Env. Bio-Sci., 30(1):197-200.

Chauhan., R. S. (2001). Status of composite culture of carps at three management levels in tarai region of Uttaranchal. In: Proceedings of the National Symposium on Fish Health Management and Sustainable Aquaculture: pp.11-14.

Chauhan., R. S. (2014). Growth performance, length- weight relationship, body condition and carcass composition of Cyprinus carpio fed with poultry dropping incorporated diets. J. Ecophysiol. Occup. Hlth. 14 (1\&2):103-109.

Citarasu, Thavasimuthu (2010). Herbal biomedicines: a new opportunity for aquaculture industry. Aquacult. Int.18: 403-414.

Das, B.K. (2008).The effect of Euglena viridis on immune response of Rohu, Labeorohita(Ham.). Fish and Shellfish Immunology, 26(6): 871-876.

DAHDF (2016). Annual Report 2015-16. Department of Animal Husbandry, Dairying and Fisheries, Ministry of Agriculture, New Delhi.

Eknath, A.E. and Doyle, R.W. (1985).Indirect selection for 
growth and life-history traits in Indian carp aquaculture. 1.Effects of Brood stock management. Aquaculture 49:73-84.

FAO (2016). The State of World Fisheries and Aquaculture. Food and Agriculture Organization, Rome.

Hartman, J. (1983). Two feeding strategies of young fishes.Arch. Hydrobiol,96: 496-509.

Innocent, B. Xavier, Fathima, Syed Ali M. and Dhanalakshmi (2011). Immunostimulatory activity of Coriandrum sativum and resistance to Aeromonas hydrophila in Catla catla. Journal of Applied Pharmaceutical Science, 1(7): 132-135.

Izquierdo, M.S., Fernandez-Palacios, H. and Tacon, A.G.J. (2001). Effect of broodstock nutrition on reproductive performance of fish.Aquaculture, 207: 97-109.

Jezierska, A., Jowoko, G. and Kowski, K.K. (1979). Respiratory metabolism of carp larvae under constant and cyclically fluctuating temperature conditions. Cultivation of fish fry and its live food. Europ. Maricult. Soc. Publ.4: 243-255.

Jhingaran, V. G. (1991). Fish and Fisheries of India. Hindustan Publishing Corporation, India. 727p.

Kour, D., Sharma, L.L. and Sharma, B.K. (2004).Use of herb, Bala (Sidacordifolia Linn.) as growth promoter in the supplementary feed of Cirrhinus mrigala (Ham.).Indian Journal of Fisheries51(4): 501-504.

Kumar, R., Sharma, B.K. and Sharma L.L. (2007).Impact of Glycyrrhiza glabra Linn.as growthpromoter in the supplementary feed of an Indian major carp Cirrhinu smrigala (Ham.). Indian Journal of Animal Research, 41 (1): $35-38$

Kumari, J., Sahoo, P.K., and Giri, S.S. (2007). Effects of polyherbal formulation Immu Plus on immunity and disease resistance of Indian major carp, Labeo rohita at different stages of growth. Indian Journal of Experimental Biology 45:291-298.

Nazir, I., Arya, P. and Chauhan, R.S. (2015). Evaluation of growth promoting potential of probiotic Biosyn in fingerlings of Indian major carp Labeo rohita. National Journal of Life Science 12(2):173-175.

Olusola, S.E., Emikpe, B.O. and Olaifa, F.E. (2013). The potentials of medicinal plant extracts as bioantimicrobials in aquaculture. Int. J. Med. Arom. Plants, 3(3): 404-412.

Punitha, S.M.J., Babu, M.M., Sivaram, V.M., Shankar, V.S., Dhas, S.A., Mahesh, T.C., Immunuel, G. and Citarasu, T. (2008). Immunostimulating influence of herbal biomedicines on nonspecific immunity in Grouper (Epinephelus tauvina) juvenile against Vibrio harveyi infection. Aquacult. Int.16: 511-523.

Rajeshwari, S., Pavaraj, M., Muthu, R. and Rajan, M.K. (2015).Effect of Melia azedarach extract on some selected haematological parameters of Catla, (Catla catla). World Applied Sciences Journal33(4):564-566.

Sahu, M.K., Swarnakumar, N.S. and Sivakumar, K. (2008). Probiotics in aquaculture: importance and future perspectives. Indian Journal of Microbiology, 48:299-308.

Sinha, K., Mishra, N. P., Singh, J. and Khanuja, S. P.S. (2004). Tinospora cordifolia (Guduchi), a reservoir plant for therapeutic applications: A Review. Indian Journal of Traditional Knowledge, (3): 257-270

Sivagurunathan, A., Meera, K.A. and Innocent, B. X. (2011).Investigation of immunostimulant potential of Zingiber officinale and Curcuma longa in Cirrhinus mrigala exposed to Pseudomonas aeruginosa- Haematological assessment. International Journal of Research in Ayurveda and Pharmacy,2(3): 899-904. 